\title{
Bladder Fistula
}

National Cancer Institute

\section{Source}

National Cancer Institute. Bladder Fistula. NCI Thesaurus. Code C79849.

An abnormal communication between the urinary bladder and another org an or anatomic site. 